\title{
Negative Impacts of Abattoir Wastes on the Physico-Chemical Parameters of Odo River, Cele Ijesha, Lagos Nigeria.
}

\author{
Ajetunmobi Asibiallau O., Ogunfowora Abiodun O. \\ Department Of Science Laboratory Technology Lagos State Polytechnic
}

\begin{abstract}
The influence of abattoir wastes on the Odo River Cele Ijesha, Lagos was undertaken during the rainy season in the month of August 2013, to assess the level of Biochemical Oxygen Demand, Dissolved Oxygen, Chemical Oxygen Demand, Temperature, Total Suspended Solid, $p H$ and Ammonia. The deterioration of water quality is evident by high BOD $\left(24.0 \mathrm{mg} / \mathrm{L}^{-1}\right), C O D$. The results indicated that abattoir wastes have adverse effect on the water quality. This observation showed that with a continuous discharge of wastes into the aquatic ecosystem could lead to the death of aquatic organism in the water bodies.
\end{abstract}

Key words: pollution, waste, degradation, slaughter and abattoir.

\section{Introduction}

The manufacturing of animal products for human consumption (meat and dairy products) or for other human needs (leather), leads inevitably to the production of waste.(NEDECO,2010) Under traditional conditions, the quantities of products processed in a certain area used to be small and by-products were better utilized. This resulted in the production of smaller quantities of waste than at present (Chiaudani and Premazzi, 2012).

Nature is able to cope with certain amounts of waste via a variety of natural cleaning mechanisms. However, if the concentration of waste products increases, nature's mechanisms become overburdened and pollution problems start to occur (Dick, 2005). Usually, small-scale home processing activities produce relatively small amounts of waste water. Nature can cope with these. Yet as a consequence of the increasing emphasis on large scale production (e.g. reasons of efficiency, increase in scale of production and hygiene) considerably greater amounts of waste will be produced and steps will have to be taken to keep this production at acceptable levels.

Also, methods will have to be found or developed for more efficient use of by-products and for improved treatment of waste products. Because large scale processes are not easy to survey, the checking of waste production is a problematic undertaking and special efforts are needed to find out where in the production process waste is produced. (Berker, 2012).

An example that illustrates the relationship between the scale of production and the production of waste is that of the production of hard cheese. Before large scale production of cheese came into existence, whey was considered as a valuable by-product that could be used as animal feed (Enderlein, 2009). In the Netherlands, about 50 percent of all the milk produced is used for the production of cheese. The whey which is produced in the process could lead to enormous environmental problems partly because the costs of transport of this whey to the farm for use as animal feed are a costly affair.

Only after environmental considerations had become more important, efforts were made to solve this problem (Barker,2003). Eventually this has resulted in the establishment of a production line of whey-powder which is now-a-days considered a valuable product.

The example also shows that the borderline between a waste product and a useful product is sometimes hard to draw.

\section{Background Of The Study}

In the present study, major attention will be given to the impact on the environment of:

i. The slaughter processes at slaughterhouse,

ii. The storage, preservation and processing of hides; and

iii. The processing of milk, all at industrial levels, for the discussion concerning the waste production within ach of these animal-product-processing industries, it is worth looking at operations that precede and follow the industrial waste producing processes.

- In Slaughterhouses: the animals are reared, fattened and transported to the slaughterhouses. After processing, the meat is stored before it is transported to retail outlets. The "preceding" activities produce manure etc. while for storage and transport (follow activities) cooling facilities are needed. This puts a heavy claim on energy sources. (Adelegan, 2002) 
- In tanneries: hides produced at slaughterhouses must be stored. To prevent spoilage, they should be pickled and preservatives should be added. The methods used to process hides will to some extent determine the durability of the produced leather (FAO, 2003). The production of more durable leather leads to smaller quantities of leather waste. Chrome tanned leather and leather products contain about 2-3\% of dry weight chromium. Worn out leather products, such as shoes and jackets, are frequently dumped at municipal dumping places.

- Before its collection and transportation to a processing plant, milk is produced and stored at the farm (FAO, 2003). This requires energy and leads to spoilage of milk and production of wastewater (tank cleaning). After the processing at the plants, dairy products are packed and stored and transported to retailers. At the end of its lifeline, packing material finishes in the form of solid waste (NEDECO, 2010). The repeated use of milk bottles produces waste water (after cleansing). At the site of the consumer, storage makes a demand on energy and incorrect storage or usage may lead to spilling. It has been estimated that $2-10 \%$ of all dairy products are wasted by the consumer as a result of spoilage. (Benka et al., 2012) In general terms, waste products may occur as waste water, solid material, volatile compounds or gasses that are discharged into the air.

Human activities contribute impurities in the form of industrial, domestic, agricultural and chemical wastes to water bodies (Dick, 2005). Wastes from meat processing operations tend to be worrisome due to their high content of putresible organic matter, which can lead to the depletion of oxygen and cause water supply impairment (Figueras, 2000). The meat processing wastes come from stockyards, abattoirs and packing plants, etc. all these contain blood, fats, protein, gut contents, heavy metals, antibodies, hormones and other substances (Berker,2012).

In Nigeria, many abattoirs dispose of their waste directly into streams or rivers and also use water from the same source to wash slaughtered meat (Adelegan, 2002). Such is the situation in the Odo abattoir operation. Benka Coker and Ojor (2012), carried out a baseline survey on the influence of continual discharge of untreated abattoir wastewater on the water quality of Ikpoba hill, Benin City, their work was focused on the slaughterhouse waste standards and food processing industries. Findings indicated that slaughterhouse waste did not meet established standards for food processing industries and therefore posed a potential health hazard to the public.

This study is aimed at identifying the negative impact of abattoir waste on the receiving water bodies of Cele Ijesha River and also provides information on the water pollutants, since the river is the main source of water for drinking purposes, traditional recreation and to a certain extent used for industrial purposes.

\section{STUDY AREA}

The abattoir is situated along the Cele Ijesha road by the Odo market. It is located at the bank of elevated concrete floor slab, which serves as a slaughtering surface. A certain amount of animals such as cows, goats and pigs are slaughtered daily. In the Cele-Odo abattoir, an estimate of $80-90$ cows are slaughtered on weekdays. The cows are killed manually by falling the cows with strong thick ropes. The cows are killed with sharp deep knife cut through the neck, releasing blood and led to the complete death of the animals include blood, flesh particles, soluble protein, urine, faeces and other organic materials.

There are small drainage channels around the slab that is connected to a large channel through which the animal waste is being discharge into which the animal waste is being discharged into the water body. Water traps are mounted around the slab area used to supply the water in preparing the slaughtered animal in washing the slab after the slaughtering of the animals.

Station 1: Slaughterhouse wastewater at the point of discharge (source). Station 2: is 10m upstream from the source. The water flows from station 2 to 1 . At high tides, the water flows upstream and when the flow will be backwards. Hence at low tides, the water flow direction changes at flowing in normal direction (Dick,2005). However, only after environmental consideration had become more important, efforts were made to solve this problem of abattoir pollution, but all efforts proved abortive, due to lack of proper environmental regulation.

\section{Materials And Methods}

The samples used in determining the influence of the abattoir waste on the receiving river were collected in 30cl plastic bottles once daily in the evenings, from two stations along the Cele Odo River during the same flow direction because pollution levels are significantly in fluctuated by human activity. The sampling was done during the wet season, in August 2013. The samples were taken to the laboratory for further analysis within 24 hours of collection.

Physico-chemical parameters such as Biochemical Oxygen Demands $\left(\mathrm{BOD}_{5}\right)$, Chemical Oxygen demands (COD), Dissolve Oxygen (DO), total suspended solid (TSS), temperature $\left({ }^{\circ} \mathrm{c}\right.$ ) and ammonia were used to determine the water quality and pollution effects from abattoir waste. Water samples for the determination of $\mathrm{BOD}_{5}, \mathrm{DO}$, COD, TSS and temperature were collected for each sample station. The Azide modification method 
was used to determine the initial dissolved Oxygen (DO), $\mathrm{BOD}_{\mathrm{S}}$, was computed from the difference between initial and final DO, Chemical Oxygen demand is a measure of the oxygen equivalent of that portion of the organic matter in a sample that is susceptible to oxidation by a strong chemical Oxidan, Temperature measurement of surface water were under-taken with a mercury in glass thermometer (Centigrade ${ }^{\circ} \mathrm{C}$ ), while phenol hyphochloride (phonate) method was used to measure Ammonia.

\section{Results}

The results values obtained showed that $\mathrm{BOD}_{5}, \mathrm{COD}$, and ammonial were higher in station $1, \mathrm{BOD}_{5}$ $\left(24.0 \mathrm{mg} / \mathrm{L}^{-1}\right) \mathrm{COD}\left(20.800 \mathrm{mg} / \mathrm{L}^{-1}\right)$ and Ammonia $\left(20 \mathrm{mg} / \mathrm{L}^{-1}\right)$ while the lowest values occurred in station 2 : BOD $_{5}\left(11.20 \mathrm{mg} / \mathrm{L}^{-1}\right)$ COD $(9.2 \mathrm{mg} / \mathrm{L})$ and Ammonia $\left(1.04 \mathrm{mg} / \mathrm{L}^{-1}\right)($ Table 1$)$ Total Suspended Solid (TSS) had the highest value at station $1\left(5,120 \mathrm{mg} / \mathrm{L}^{-1}\right)$ and lowest value was recorded in station $2\left(440 \mathrm{mg} / \mathrm{L}^{-1}\right)$ while temperature value is high in station $2\left(19^{\circ} \mathrm{C}\right)$ and had the lowest value at station $1\left(18^{\circ} \mathrm{C}\right)$. However station $2 \mathrm{P}^{\mathrm{H}}$ value is higher than that of station $1 \mathrm{P}^{\mathrm{H}}$ value, having 6.7 to 6.5 values.

Table 1: The level BOD, COD, $\mathrm{pH}, \operatorname{Temp}\left({ }^{\circ} \mathrm{C}\right) \mathrm{TSS}$ and Ammonia in the water samples

\begin{tabular}{|l|l|l|l|}
\hline Stations/Locations & 1 & 2 & FEPA LIMIT \\
\hline $\mathrm{BOD}\left(\mathrm{mg} / \mathrm{L}^{-1}\right)$ & 24.0 & 11.20 & 6.0 \\
\hline $\mathrm{COD}\left(\mathrm{mg} / \mathrm{L}^{-1}\right)$ & 20.800 & 9.2 & 10.5 \\
\hline Temperature $\left({ }^{\circ} \mathrm{C}\right)$ & 18 & 19 & 27 \\
\hline $\mathrm{TSS}\left(\mathrm{mg} / \mathrm{L}^{-1}\right)$ & 5,120 & 440 & $>10$ \\
\hline $\mathrm{NH}_{3}{ }^{+}\left(\mathrm{mg} / \mathrm{L}^{-1}\right)$ & 20 & 1.04 & 0.5 \\
\hline $\mathrm{pH}$ & 6.5 & 6.7 & 7.0 \\
\hline
\end{tabular}

\section{Discussion}

It is important to find out if the discharge of organic waste (abattoir waste) influx has any significant adverse effect on the aquatic ecosystem. The measurable physico-chemical properties considered in this study were $\mathrm{BOD}_{5}, \mathrm{DO}, \mathrm{COD}$, temperature, $\mathrm{pH}$, Ammonia and TSS. The concentrations of these parameters in natural aquatic ecosystem varied in response to abattoir waste influx. Waste biodegradation is usually associated and responsible for such observed changes. $\mathrm{BOD}_{5}$ and $\mathrm{COD}$ observed in this study were generally higher than the standards allowed to be discharged into the Nigerian inland water . Comparing these values with other findings made by Benka, Coker and Ojo , they were greater than $4.0 \mathrm{mg} / \mathrm{L}^{-1}$ and therefore indicated high degree of pollution in the water body.

The values obtained for ammonia during the referred periods were higher than regulatory limits/standards and this indicated pollution and degradation of the studied Cele Ijesha, Odo River. However, the concentration of ammonia in station 1 was very high as compared to station 2.

This is due to the presence of high nitrogen content in the organic waste (abattoir waste). This nutrient (nitrogen) is also essential for plant growth and as such contributes to eutrophication due to algal bloom in the river.

The observed fluctuation in temperature was considered normal with respect to the geographic characteristics of the Lagos temperature which has been described as humid/ semi-hot equational type. The low temperature recorded in this study is as a result of rainfall and flood inflow during the rainy season period which exerted some cooling influence. This effect was interfered with by the heat generated/absorbed during the metabolic processes of both waste biodegradation and aquatic organisms.

TSS of the sample was very high and this shows that both the abattoir waste water contains high quantities of organic and inorganic particles.

\section{Conclusion}

Many abattoir waste emitted into the river environment from anthropogenic sources pose a threat to the functioning of aquatic ecosystems and to use of water for various purposes. The need for strengthened measures to prevent and to control the release of these substances into the aquatic environment has led many countries to develop and to implement water management policies and strategies based on, amongst others, water quality criteria and objectives.

\section{Recommendations}

To provide further guidance for the elaboration of water quality criteria and water quality objectives for inland surface waters, and to strengthen international co-operation the following recommendations have been put forward.

i. The precautionary principle should be applied when selecting water quality parameters and establishing water quality criteria to protect and maintain individual uses of waters. 
ii. In setting water quality criteria, particular attention should be paid to safeguarding sources of drinkingwater supply. In addition, the aim should be to protect the integrity of aquatic ecosystems and to incorporate specific requirements for sensitive and specially protected waters and their associated environment, such as wetland areas and the surrounding areas of surface water which serves as sources of food and as habitats for various species of flora and fauna.

iii. Water-management authorities should be required to take appropriate advice from health authorities in order to ensure that water quality objective are appropriate for protecting human health.

iv. Under no circumstances should the setting of water quality objectives (or modification thereof to account for site-specific factors) lead to the deterioration of existing water quality.

v. Water quality objectives for multipurpose uses of water should be set at a level that provides for the protection of the most sensistive use of water body. Among all identified water uses, the most stringent water quality criterion for a given water quality variables should be adopted as a water quality objective.

vi. Established water quality objectives should be considered as the ultimate goal or target value indicating a negligible risk of adverse effects on use of the water and on the ecological functions of waters.

\section{References}

[1]. Alabaster, J.S. and Loyd, R. (2000) Water Quality Criteria for Freshwater Fish. $2^{\text {nd }}$ edition. Published on behalf of Food and Agriculture Organization of the United Nations by Butterworth, London, $361 \mathrm{pp}$.

[2]. Berker, J.C. (2012). Lagoon Design and Management for Livestock. Waste Treatment and Storage; water quality and management for North Carolina cooperative Extension, North Carolina, U.S.A.

[3]. Benka-Coker, M.O. and Ojior (2012): Effect of Slaughterhouse wastes on the water quality of Ikpoba river, Nigeria; Bioresource Publication, Kolkatta, India (Incomplete ref: No P. \& Vol. \& P.)

[4]. Chiaudani, G and Premazzi, G. (2006) Water Quality Criteria in Environmental Management. Report EUR 11638 EN, Commission of the European Communities, Luxembourg.

[5]. Clerk, R.B. (2011). Marine Pollution Claradon Press oxford. P 21 - 24

[6]. Dick, .I. (2005) Water Quality Criteria, Goals and Standards. Second WHO Regional Seminar on Environmental Pollution: Water Pollution, manila, WPR/W.POLL/3, WHO Regional Office for the Western Pacific, Manila.

[7]. Enderlein, R.E. (2010) Protecting Europe's water resources: agricultural policy requirements in Europe. HRVAT. VODE, 4(15), 69 $-76$.

[8]. FAO, (2008) Quality Criteria for Water. FAO-440/9-76-023, United States Environmental Protection Agency, Washington, D.C.

[9]. Figueras, J.J. (2010). Monitoring Bathing waters; a practical Guide to the design and implementation of assessment and monitoring program for WHO pp $13-17$.

[10]. NEDECO (2010). The waters of the Niger Delta Reports of an investigation by NEDECO (Netherland engineering consultant). The Haque pp $210-228$ 